\title{
Myocardial infarction in young men Study of risk factors in nine countries ${ }^{1}$
}

\author{
Martin A. Dolder² and Michael F. Oliver \\ From the Department of Cardiology, Royal Infirmary, Edinburgh, Scotland
}

In order to determine whether the development of myocardial infarction in different countries is associated with different risk factors, 240 male survivors, aged 40 or less, were studied in nine countries.

In the seven centres in developed countries (Auckland, Melbourne, Los Angeles/Atlanta, Cape Town, Tel Aviv, Heidelberg, and Edinburgh) there was a high prevalence of risk factors, particularly of hyperlipidaemia and cigarette smoking. The prevalence of hypertension, obesity, hyperglycaemia, and hyperuricaemia varied from centre to centre. Risk factors were less prevalent in Bombay and Singapore: the most common risks operating in Bombay seemed to be cigarette smoking and hyperglycaemia, while in Singapore cigarette smoking was the commonest.

The mean age of the whole group was 35.4 years. Serum cholesterol levels of $7.25 \mathrm{mmol} / \mathrm{l}(280 \mathrm{mg} / \mathrm{dl})$ or more were present in 25 per cent of all patients, serum triglyceride levels of $2.26 \mathrm{mmol} / \mathrm{l}(200 \mathrm{mg} / \mathrm{dl})$ or more in 35 per cent. 80 per cent of the patients were smokers, and 15 per cent were either treated for hypertension before myocardial infarction or had a raised blood pressure after myocardial infarction. Obesity was found in I9 per cent of all patients and serum uric acid levels over $0.5 \mathrm{mmol} / \mathrm{l}(8.5 \mathrm{mg} / \mathrm{dl})$ in 17 per cent. Io per cent of all patients were either treated for diabetes mellitus before myocardial infarction or showed an abnormal glucose tolerance after myocardial infarction.

This collaborative study may help, by showing differences in the prevalence of risk factors, to indicate to each centre and to national and to international organizations, the direction for their future studies into the causation and prevention of myocardial infarction in young men.

\section{Contributors}

Co-ordinators: Martin A. Dolder and Michael F. Oliver.

Consultant: Frederick H. Epstein, Department of Social Medicine, University of Zürich, Zürich.

Australia: $\quad$ R. R. H. Lovell and P. Valentine, Department of Medicine, Royal Melbourne Hospital, Melbourne.

Germany: G. Schettler, E. Nüssl, and R. Stahlheber, Ludolf-Krehl-Klinik, Heidelberg.

Great Britain: M. F. Oliver, Martin A. Dolder, and M. J. Rowe, Department of Cardiology, Royal Infirmary, Edinburgh.

Received 2 December 1974.

${ }^{1}$ This work was supported by the I.S.C. Scientific Council for Atherosclerosis and Ischaemic Heart Disease.

${ }^{2}$ M. A. Dolder was supported by a grant of the Swiss National Funds in connexion with the Royal Society, London. Present address: Department of Cardiovascular Surgery, University of Berne, Switzerland.

\begin{abstract}
India: $\quad$ J. Pinto, Esperanca, Bombay.
Israel: $\quad$ H. Neufeld, Heart Institute, Tel Hashomer Hospital, Tel Aviv.

New Zealand: P. J. Scott, K. P. O'Brien, and I. Prior, Medical Unit, Auckland Hospital, Auckland.

Singapore: C. Toh, N. B. Tau, and C. H. Lin, Department of Clinical Medicine, General Hospital, Singapore.

South Africa: B. M. Kennelly, Cardiac Clinic, Groote Schuur Hospital, Cape Town.

U.S.A.: $\quad$ Nanette $\mathrm{K}$. Wenger, Emory University School of Medicine, Atlanta, and D. Blankenhorn, School of Medicine, University of Southern California, Los Angeles.
\end{abstract}

The incidence of coronary heart disease varies greatly between different parts of the world (Epstein, 1965, Keys, 1970) and comparative estimates of rates have been derived mostly from mortality figures. Comparisons of survivors have seldom been 
attempted because of dissimilarity in population sampling and methodology. This study was undertaken on an international basis in order to try to obtain more uniform data in young male survivors of myocardial infarction. Epidemiological data relating predisposing factors to coronary heart disease can really only be applied to the particular country in which they were collected, though considerable similarity exists in many developed countries. An attempt was made therefore to determine whether differences exist in different parts of the world, in the prevalence of risk factors and other findings in young men who developed myocardial infarction. Men under the age of 40 were chosen for study and the results from 240 patients with myocardial infarction are reported here. This series is, as far as we know, the largest reported and represents the experience over a 15 -month period in 10 major hospitals.

\section{Design of study}

There were to participating centres in 9 countries all over the world (Table I). Of the ro centres, 3 were located in Asia, 2 in Europe, 2 in North America (U.S.A.), $I$ in Africa, I in Australia, and I in New Zealand. The co-ordination of the study and the evaluation of the results were undertaken in Edinburgh. In 1970, a pilot study was conducted in order to assess the feasibility of the project and to establish the design of the study. The main study was undertaken from I January I972 to 3I March 1973. During this time, each centre collected consecutive patients presenting at the age of 40 or under with myocardial infarction, who attended a second time 6 weeks to 6 months after the infarct, when the clinical and laboratory indices were recorded. The study comprised only the survivors who could be re-examined within the required period. Patients who died after the acute stage and before they could be reviewed or patients who could not be reviewed within 6 weeks to 6 months after infarct because they lived too far away from the hospital or because they refused to co-operate were not included in the study. Fifteen patients were excluded by the co-ordinating centre before the evaluation of the results, because data were incomplete.

The following data were recorded for each patient during recovery from the acute episode of myocardial infarct: criteria for diagnosis, family history, previous medical history, and smoking history. The mean interval between the myocardial infarct and the second examination, when the clinical data and laboratory indices were recorded, was 13.9 weeks (Table I). Of all the patients, 4 per cent were studied between 6 weeks and 8 weeks, 76 per cent between 2 and 4 months, and 20 per cent between 4 and 6 months after infarction. At this examination, the physical findings and height and weight were noted, a 12-lead electrocardiogram was recorded and a posteroanterior chest $x$-ray was obtained. Venous blood was taken in the fasting state for estimation of serum cholesterol, triglycerides, glucose, uric acid, haemoglobin, haematocrit, and blood groups. All biochemical and haematological determinations were made by the individual centres in their own laboratories, which sent samples for the estimation of serum cholesterol and triglycerides to the Lipid Standardization Laboratory, Centre for Disease Control, Atlanta, Georgia. In addition, in all centres except Bombay, the glucose tolerance was measured using capillary blood after $50 \mathrm{~g}$ glucose orally. A normal response was defined according to the criteria of the British Diabetes Association (Fitzgerald and Keen, 1974) by a capillary blood sugar level of less than $9.9 \mathrm{mmol} / \mathrm{l}(\mathrm{I} 80 \mathrm{mg} / \mathrm{dl})$ after I hour and less than $6.6 \mathrm{mmol} / \mathrm{l}(\mathrm{I} 20 \mathrm{mg} / \mathrm{dl})$ after 2 hours. If both the I- and 2-hour measurements exceeded these values, the glucose tolerance was considered to be diabetic. All electrocardiograms were coded according to the Minnesota code in Edinburgh by the same trained technician.

TABLE I Study group (clinical data)

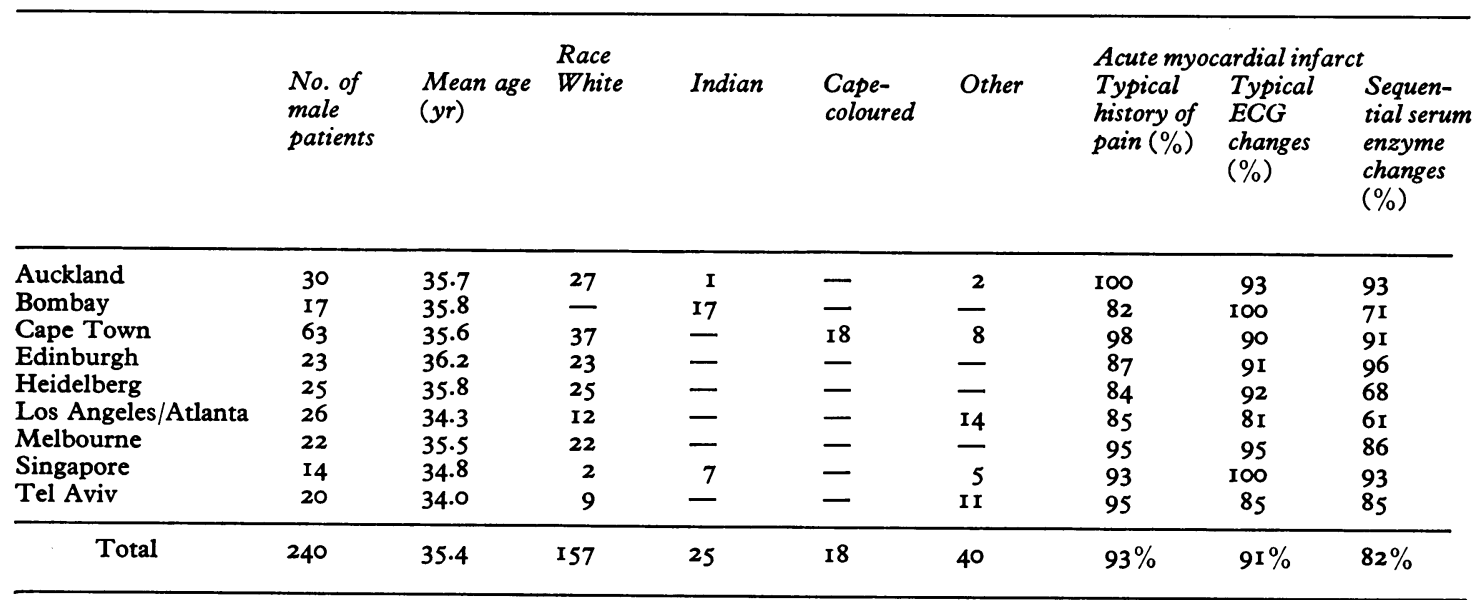


All questionnaire forms were sent after completion to the co-ordinating centre for further processing. All data were transferred to punch cards and data processing was performed on an IBM $370 / 155$ computer in the Edinburgh Regional Computing Centre. Statistical significance was calculated by means of the $\chi^{2}$ test using arbitrary cutting points to separate 'normals' from 'abnormals'.

\section{Study group}

The criteria for diagnosis of myocardial infarction were those laid down by the World Health Organization (1959) and included the history, electrocardiogram, and serum enzyme changes. According to this definition, 93 per cent of patients had a typical history and 9I per cent had definite electrocardiographic changes (development of abnormal $Q$ wave with or without associated injury current), while sequential serum enzyme changes were present in 82 per cent. In all, 99 per cent of patients had, according to the WHO definition, a definite myocardial infarct while in I per cent the diagnosis was classified as possible (Table I).

A total of 240 male patients, aged 40 or under, who survived the acute myocardial infarction were studied (Table I). The patients of the two centres in the U.S.A., Los Angeles (17) and Atlanta (9) were combined in order to increase the size of the sample. This was done after assessing all results separately and without finding striking differences between these two centres.

The mean age of the 240 patients at the time of the myocardial infarct was 35.4 years (Table I). Twenty were under the age of 30,55 were between 30 and 35 , I65 were between 35 and 40 .

The race of the patients is shown in Table $I$. The white race with 157 patients was the biggest group and accounted for two-thirds of all patients. In Edinburgh, Heidelberg, and Melbourne only whites were studied. Indians in Bombay and the coloured in Cape Town (people of mixed racial origin, e.g. European-African or African-Asian) were studied in these centres. In addi- tion, I6 Asians, 5 Blacks, 2 Maoris, 5 Arabs, 3 Chinese, and 9 of unknown race were investigated in different centres.

\section{Results}

Serum cholesterol

The results of serum cholesterol after myocardial infarction have been plotted as a cumulative frequency distribution curve (Fig. I). The two curves for Singapore and Bombay are separated from the other seven centres and show a shift to the lower values on the left. Hypercholesterolaemia was defined as serum cholesterol of $7.25 \mathrm{mmol} / \mathrm{l}$ (280 $\mathrm{mg} / \mathrm{dl}$ ) or more (Carlson and Böttiger, 1972) and was present in 25 per cent of all the subjects. Table 2 shows the centres listed in order of prevalence for serum cholesterol levels over $7.25 \mathrm{mmol} / 1$ (280 $\mathrm{mg} /$ dl.) Hypercholesterolaemia was uncommon in Singapore and Bombay, while it was much more frequent in all the other centres with an especially high prevalence in Tel Aviv and Edinburgh. Melbourne had an intermediate position between the two centres with lower values and the six with higher ones. The difference between these two groups was satistically significant $(P<0.01)$.

\section{Serum triglycerides}

The results of serum triglycerides are also shown on a cumulative frequency distribution curve (Fig. 2). As for serum cholesterol, the two curves of Singapore and Bombay are again clearly separated from the other seven centres and show a shift to the lower values on the left. Hypertriglyceridaemia was defined as a triglyceride level of $2.26 \mathrm{mmol} / 1$ ( $200 \mathrm{mg} / \mathrm{dl})$ or more and was present in 35 per cent of all subjects. Table 3 shows the centres listed in order of

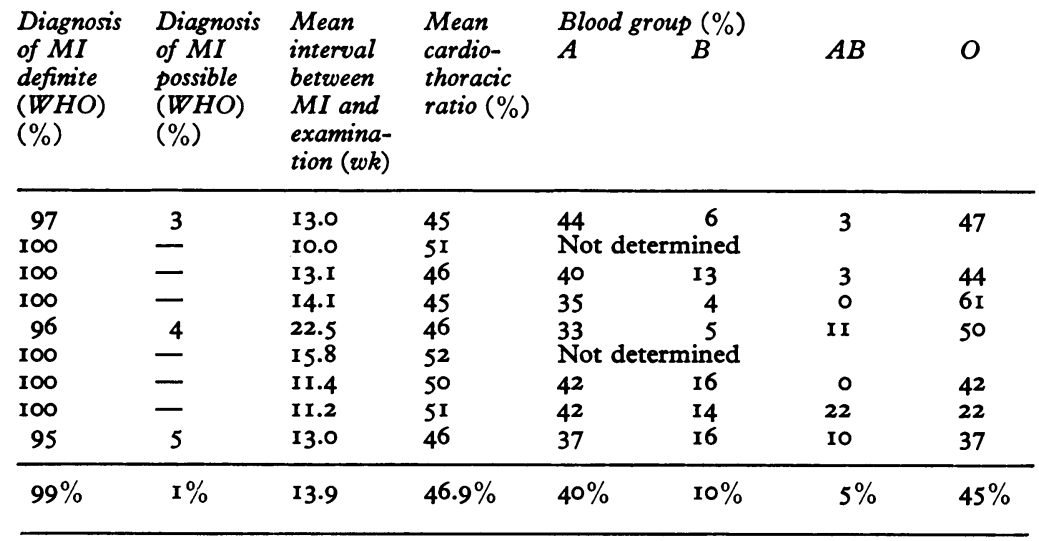




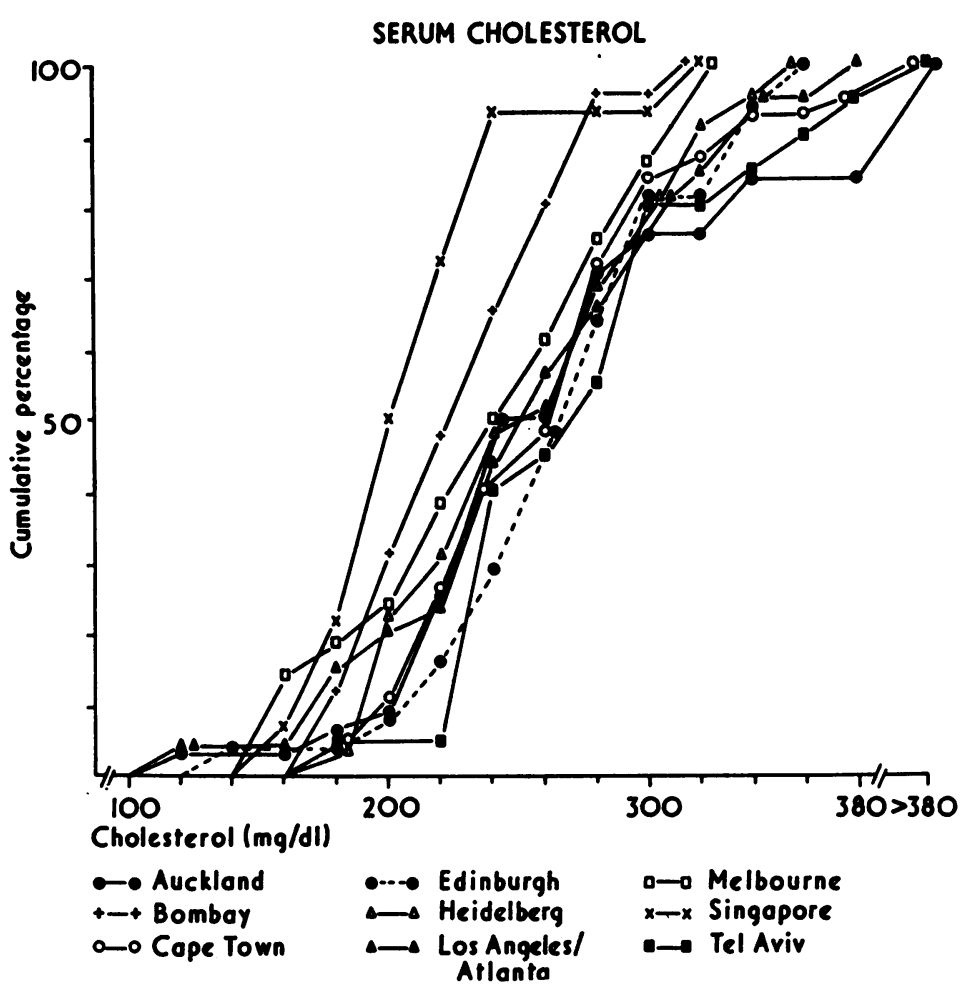

FIG. I Cumulative frequency distribution of serum cholesterol for each centre.

TABLE 2 Serum cholesterol

\begin{tabular}{|c|c|c|c|c|c|c|c|}
\hline & & & Cholestero & $\operatorname{mol}(\mathrm{l})$ & & & \\
\hline & $\begin{array}{l}\text { No. of } \\
\text { patients }\end{array}$ & $\begin{array}{l}\text { Not } \\
\text { measured }\end{array}$ & $<5.18$ & $5.18-7.23$ & $6.22-7.23$ & $\geqslant 7.25$ & $P$ \\
\hline Tel Aviv & 20 & I & $\mathbf{I}$ & 7 & 2 & $9(45 \%)]$ & \\
\hline Edinburgh & 23 & - & 2 & 5 & 8 & $8(35 \%)$ & \\
\hline Heidelberg & 25 & - & 8 & 6 & 4 & $7(28 \%)$ & \\
\hline Auckland & 30 & $\mathbf{I}$ & 3 & 13 & 5 & $8(27 \%)$ & \\
\hline Cape Town & 63 & - & 7 & 20 & 19 & I7 $(27 \%)$ & \\
\hline Los Angeles/Atlanta & 26 & 5 & 4 & 5 & 5 & $7(27 \%)$ & \\
\hline Melbourne & 22 & 3 & 5 & 8 & 3 & $3(14 \%)$ & $P<0.01$ \\
\hline Singapore & 14 & - & 7 & 6 & - & $I(7 \%)$ & \\
\hline Bombay & 17 & - & 5 & 5 & 6 & I $(6 \%)$ & \\
\hline Total & 240 & Io $(4 \%)$ & $42(18 \%)$ & $75(31 \%)$ & $52(22 \%)$ & 6I $(25 \%)$ & \\
\hline
\end{tabular}

Conversion from SI units to traditional units: Cholesterol I mmol/1 $\approx 38.6 \mathrm{mg} / \mathrm{dl}$.

prevalence for hypertriglyceridaemia. Raised serum triglyceride levels were uncommon in Singapore and Bombay. In all the other 7 centres, hypertriglyceridaemia was much more common. The difference between Singapore and Bombay compared with the rest was statistically significant $(\mathbf{P}<0.0 \mathrm{r})$.

\section{Hyperlipidaemia}

Using the cutting-points of $7.25 \mathrm{mmol} / 1(280 \mathrm{mg} / \mathrm{dl})$ for cholesterol and $2.26 \mathrm{mmol} / \mathrm{l}(200 \mathrm{mg} / \mathrm{dl})$ for triglycerides, 20 per cent of all 240 patients showed hypertriglyceridaemia without associated hypercholesterolaemia, I5 per cent showed both hyper- 


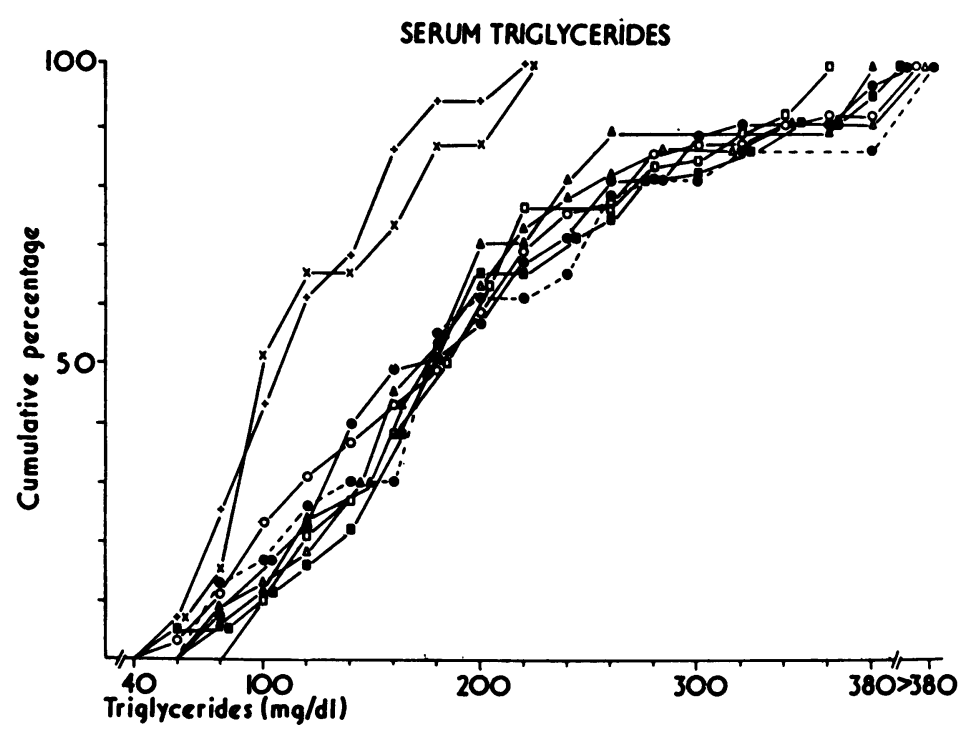

FIG. 2 Cumulative frequency distribution of serum triglycerides for each centre (symbols as in Fig. I).

TABLE 3 Serum triglycerides

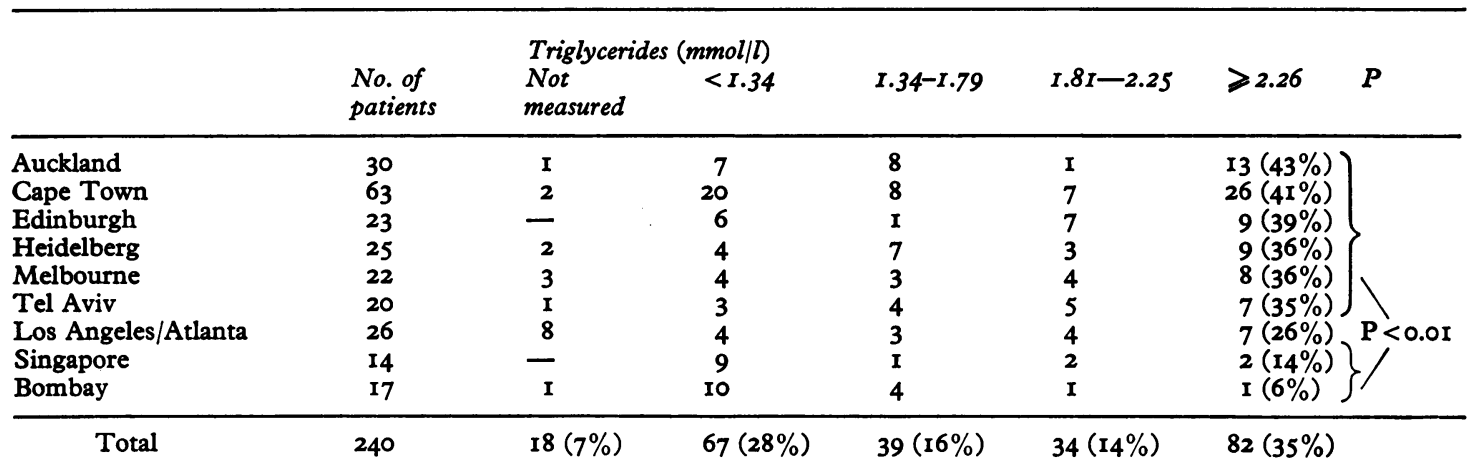

Conversion from SI units to traditional units: Triglyceride: $1 \mathrm{mmol} / 1 \approx 88.5 \mathrm{mg} / \mathrm{dl}$.

triglyceridaemia and hypercholesterolaemia, and Io per cent showed hypercholesterolaemia without associated hypertriglyceridaemia. Serum cholesterol correlated well with serum triglycerides $(r=0.63$, $P<0.05$ ), while the relative body weight correlated well with both serum cholesterol $(r=0.67, P<0.05)$ and serum triglycerides $(r=0.88, P<0.00 \mathrm{I})$.

\section{Smoking}

Regular smoking of any number of cigarettes during the last year before the myocardial infarct was the most common single risk factor and was present in as many as 80 per cent of all patients (Table 4).
Half of all smokers smoked 25 cigarettes or more a day, while only a comparatively small proportion of the smokers had less than 15 cigarettes a day. So relatively heavy smokers ( 15 cigarettes or more a day) accounted for 62 per cent of all patients. There were no statistically significant differences amongst the nine centres. Of the 20 per cent non-smokers, Io per cent were ex-smokers, and Io per cent had never smoked.

\section{Hypertension}

The results are shown in Table 5. Before the myocardial infarct 13 per cent of all 240 patients had 
TABLE 4 Cigarette smoking

\begin{tabular}{|c|c|c|c|c|c|c|c|c|}
\hline & $\begin{array}{l}\text { No. of } \\
\text { patients }\end{array}$ & $\begin{array}{l}\text { Smokers } \\
\text { Cigarettes/d } \\
I-14\end{array}$ & I5y & $\geqslant 25$ & $\begin{array}{l}\text { Total no. } \\
\text { of smokers }\end{array}$ & $\begin{array}{l}\text { Non-smok } \\
\text { Never } \\
\text { smoked }\end{array}$ & $\begin{array}{l}\text { Ex- } \\
\text { smokers }\end{array}$ & $\begin{array}{l}\text { Total no. } \\
\text { non-smokers }\end{array}$ \\
\hline Singapore & 14 & 4 & 4 & 4 & $12(86 \%)$ & I & I & $2(14 \%)$ \\
\hline Auckland & 30 & 2 & 10 & 13 & $25(83 \%)$ & 4 & $\mathbf{I}$ & $5(17 \%)$ \\
\hline Melbourne & 22 & I & 6 & II & I8 $(82 \%)$ & 3 & $\mathbf{I}$ & $4(18 \%)$ \\
\hline Cape Town & 63 & 5 & 26 & 22 & $53(8 \mathrm{I} \%)$ & 7 & 3 & IO $(19 \%)$ \\
\hline Tel Aviv & 20 & $\circ$ & 4 & 12 & $16(80 \%)$ & $\mathbf{I}$ & 3 & $4(20 \%)$ \\
\hline Bombay & 17 & 6 & 3 & 5 & $14(76 \%)$ & $\mathbf{I}$ & 2 & $3(24 \%)$ \\
\hline Edinburgh & 23 & 2 & 7 & 8 & $17(74 \%)$ & 2 & 4 & $6(26 \%)$ \\
\hline Heidelberg & 25 & 4 & 5 & 9 & $18(72 \%)$ & 5 & 2 & $7(28 \%)$ \\
\hline Los Angeles/Atlanta & 26 & Not known & & & I8 $(69 \%)$ & I & 7 & $8(31 \%)$ \\
\hline Total & 240 & $24(10 \%)$ & $65(31 \%)$ & $84(39 \%)$ & $191(80 \%)$ & $25(10 \%)$ & $24(10 \%)$ & $49(20 \%)$ \\
\hline
\end{tabular}

regular drug treatment for hypertension. Only 3 per per cent had a systolic pressure exceeding $21.3 \mathrm{kPa}$ $(160 \mathrm{mmHg}$ ) and 3 per cent a diastolic pressure exceeding $14.6 \mathrm{kPa}$ (I IO $\mathrm{mmHg}$ ). Taking the two groups of treated hypertension before myocardial infarction and raised blood pressure after myocardial infarction (in patients who have not been treated before infarction), together, we found that 15 per cent of all patients had hypertension. According to this definition, hypertension was most common in Melbourne and Auckland, while it was much less frequent in Edinburgh and Singapore. The difference between these two groups was statistically significant $(P<0.005)$.

\section{Relative body weight}

The relative body weight was calculated by Quetlett's formula $\frac{\mathrm{wt}(\mathrm{kg})}{\mathrm{ht}(\mathrm{cm})^{2}} \times 100$. This much-used formula has the advantage that it gives an index of relative body weight which is easily comparable in

\section{TABLE 5 Hypertension}

\begin{tabular}{|c|c|c|c|c|c|c|c|c|}
\hline & \multirow[b]{2}{*}{$\begin{array}{l}\text { No. of } \\
\text { patients }\end{array}$} & $\begin{array}{l}\text { Myocardio } \\
\text { Before }\end{array}$ & $\begin{array}{l}\text { linfarct } \\
\text { After } \\
\text { Systolic }\end{array}$ & od pressure & $\mathrm{Pa})$ & \multicolumn{3}{|c|}{ Diastolic blood pressure $(k P a)$} \\
\hline & & $\begin{array}{l}\text { Treated } \\
\text { hyper- } \\
\text { tension }\end{array}$ & $<16.0$ & $16.0-21.1$ & $\geqslant 21.3$ & $<12.0$ & $12.0-14.5$ & $\geqslant 14.6$ \\
\hline Melbourne & 22 & 5 & 4 & 18 & - & 17 & 4 & I \\
\hline Auckland & 30 & 6 & 4 & 25 & I & 20 & IO & - \\
\hline Cape Town & 63 & 9 & 28 & 33 & 2 & 51 & 9 & 3 \\
\hline Heidelberg & 25 & 4 & 3 & 22 & - & 15 & 10 & - \\
\hline Bombay & 17 & $\mathbf{I}$ & I & 15 & $\mathbf{I}$ & 14 & 3 & - \\
\hline Los Angeles/Atlanta & 26 & 3 & 15 & 9 & 2 & 21 & 3 & 2 \\
\hline Tel Aviv & 20 & 0 & 4 & 15 & I & 7 & II & 2 \\
\hline Edinburgh & 23 & I & 7 & 15 & I & 20 & 3 & - \\
\hline Singapore & 14 & I & 7 & 7 & - & 12 & 2 & - \\
\hline Total & 240 & $30(13 \%)$ & $73(13 \%$ & $159(66 \%)$ & $8(3 \%)$ & $177(74 \%)$ & $55(23 \%)$ & $8(3 \%$ \\
\hline
\end{tabular}

Conversion from SI units to traditional units: Blood pressure: $\mathrm{I} \mathrm{kPa} \approx 7.5 \mathrm{mmHg}$. 


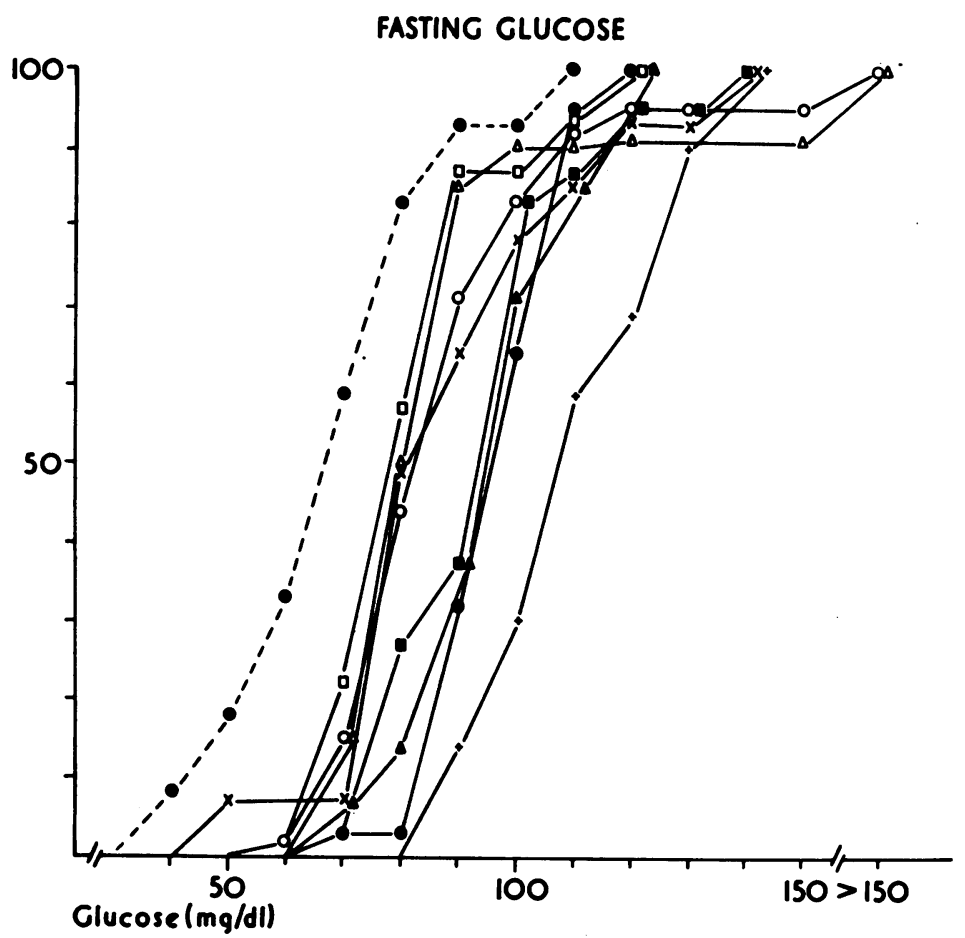

FI G. 3 Cumulative frequency distribution of fasting glucose for each centre (symbols as in Fig. I).

adults of varying height (Khosla and Lowe, 1967). This was of particular importance as the patients in Bombay and Singapore were smaller and weighed less than those in all the other centres (Table 6).

Obesity was defined as a relative body weight of 0.28 or more. This corresponds to a weight excess of

Hypertension before or after myocardial infarction
Treated hypertension
or systolic $B P \geqslant 21.3 \mathrm{kPa}$
or diastolic $B P \geqslant 14.6 \mathrm{kPa}$

$5(23 \%)$

$6(20 \%)\}$

10 $(16 \%)$

$4(16 \%)$

$2(12 \%)$

$3(12 \%)$

$2(10 \%)$

$2(9 \%)\}$

I $(7 \%)$

$35(15 \%)$ about 20 to 25 per cent over ideal body weight by the criteria of the Metropolitan Life Insurance Company (1959) and corresponds, for instance, to a male of $175 \mathrm{~cm}$ height and $85.7 \mathrm{~kg}$ in weight. Obesity was present in 19 per cent of all patients and was especially common in Heidelberg, Cape Town, and Tel Aviv (Table 6). In contrast, there were no or only a few obese men in Bombay, Melbourne, Singapore, and Edinburgh. The differences between these two groups was statistically significant $(P<0.001)$.

\section{Diabetes}

The results of the fasting glucose after myocardial infarction are shown in Fig. 3. The curve of Edinburgh is clearly separated from the others and is shifted to the left with lower values. On the other side, Bombay is clearly separated from the seven centres in the middle and shifted to the right with higher values. While 5 per cent of all 240 patients showed a fasting glucose over $6.6 \mathrm{mmol} / \mathrm{l}$ (120 mg/ dl), 29 per cent of the patients in Bombay were above this cutting point. Five per cent of all patients were treated for diabetes mellitus before the infarct with drugs or insulin. In addition, in all centres but Bombay a glucose tolerance test was carried out in a total of 154 patients using $50 \mathrm{~g}$ oral glucose. Accord- 
TABLE 6 Height, weight, and relative body weight

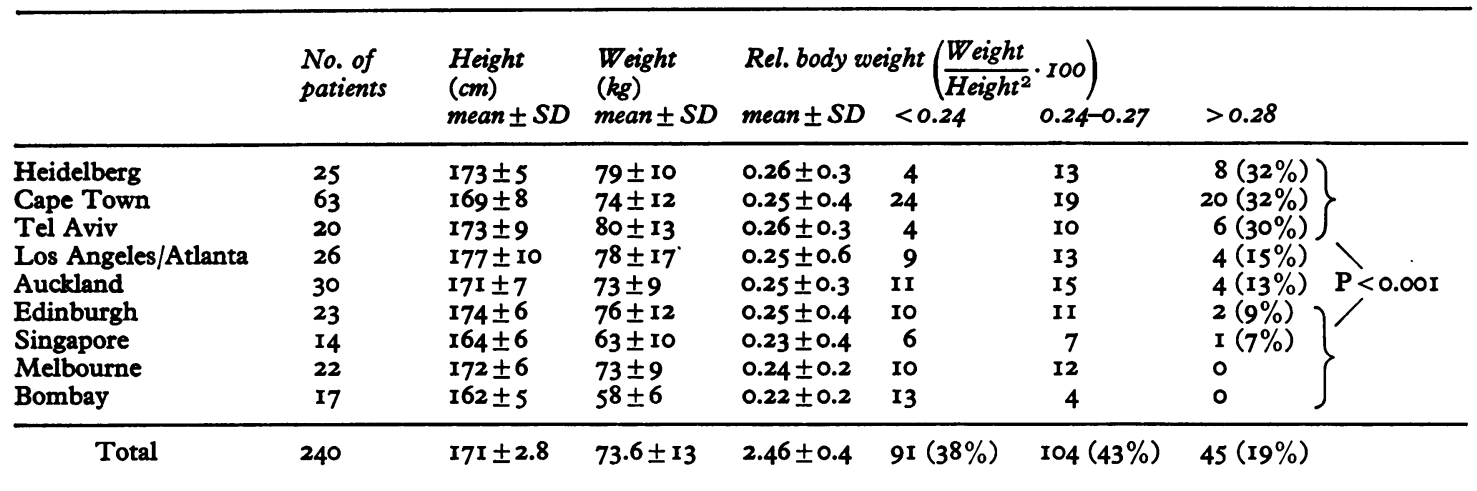

ing to the criteria of the British Diabetic Association (Fitzgerald and Keen, 1964) (I-hour value over $9.9 \mathrm{mmol} / 1$ ( $180 \mathrm{mg} / \mathrm{dl}$ ) and 2-hour value over $6.6 \mathrm{mmol} / \mathrm{l}(\mathrm{I} 20 \mathrm{mg} / \mathrm{dl}))$, a total of 12 or 8 per cent of these 154 patients showed a diabetic glucose tolerance.

\section{Uric acid}

The results of uric acid are shown on a cumulative frequency distribution curve (Fig. 4). The two curves of Cape Town and Los Angeles/Atlanta show a shift to the higher values on the right, while the curve of Bombay is clearly separated from all the others and shows a shift to the lower values on the left.

Hyperuricaemia was defined as a uric acid level of $0.5 \mathrm{mmol} / 1(8.5 \mathrm{mg} / \mathrm{dl})$ or more and was present in 17 per cent of all patients. While hyperuricaemia

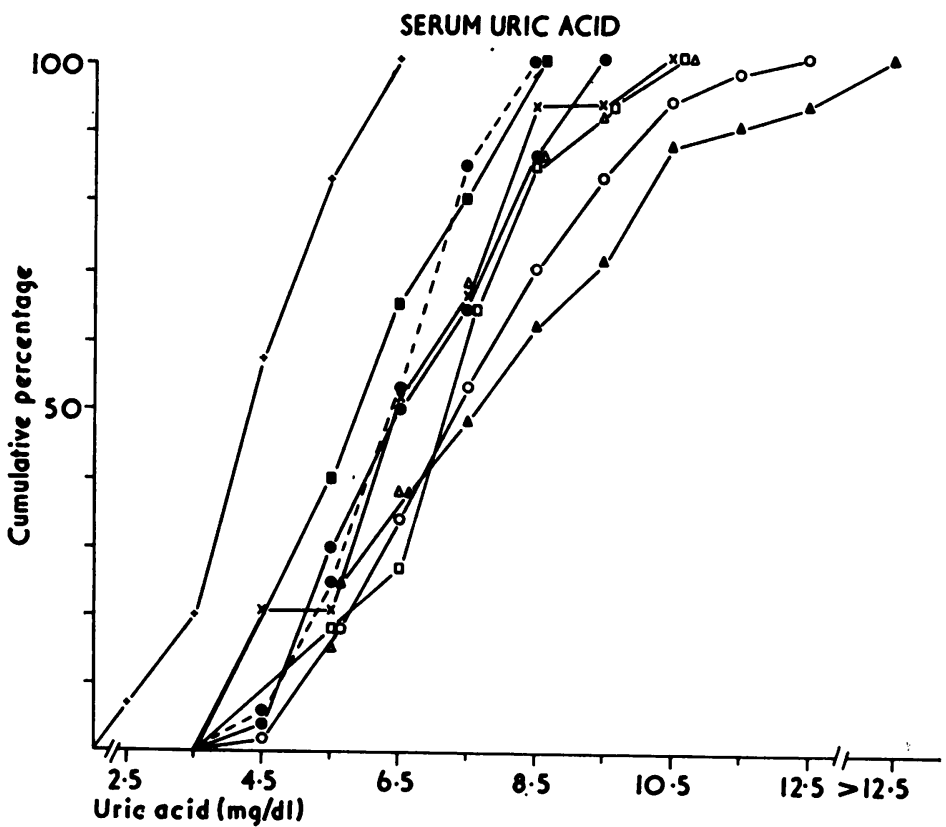

FIG. 4 Cumulative frequency distribution of serum uric acid for each centre (symbols as in Fig. I). 
was common in Los Angeles/Atlanta and Cape Town, there was no case in Tel Aviv, Bombay, and Edinburgh. The difference between these two groups was statistically significant $(P<0.00 \mathrm{r})$.

\section{Family history}

A positive family history of coronary heart disease was a common finding. Of all 240 patients, $37(15 \%)$ had lost their fathers, $17(7 \%)$ their mothers, and 8 $(3 \%)$ at least one sib as a result of myocardial infarct. Only patients who said that their parents or sibs had died as a result of infarct are included and categories such as 'death from heart disease' have been omitted. A positive family history of coronary heart disease with death of 1 or 2 parents from infarct was very common in Edinburgh $(48 \%)$ and Auckland ( $37 \%$ ), while it was less frequent in Bombay (12\%) and Singapore ( $7 \%$ ).

\section{Other findings (Table I)}

The mean cardiothoracic ratio was 46.9 per cent and varied only slightly from centre to centre. The mean haematocrit was 46.3 per cent. The haematocrit was below 40 per cent in 3 per cent of all patients, while it was above 50 per cent in 15 per cent.

\section{Discussion}

This study was specially designed in order to get comparable results about young survivors of myocardial infarct and the prevalence of risk factors for coronary heart disease among them in different parts of the world, and not to record the incidence of myocardial infarct in young men in these countries. The patients were inevitably selected since they were admitted to hospitals with highly specialized units, and admission rates to hospitals will differ from country to country. Furthermore, the results relate only to the survivors; if all subjects, those who died and those who survived, were considered, the results might possibly be different. A sample of young men with myocardial infarction was used on the presumption that predisposing factors should be more evident when there is premature coronary heart disease. It is realized that low incidence areas may be in transition to higher incidence and that useful information might also be obtained from older people whose ways may have changed less.

An international study like this poses many problems. One is the lack of any control group without coronary heart disease, studied under similar conditions. Without this it is difficult to interpret the findings in the subjects studied. As there are big differences in the prevalence of risk factors in the different centres, every centre would have to establish a control group of its own. In several participating countries, this would have been a very difficult undertaking. Another is the comparability of the results. Every effort was undertaken to standardize the methods and these included meetings of all participants, the use of a uniform questionnaire, the analysing and coding in Edinburgh of all electrocardiograms according to the Minnesota code, the evaluation of all results in one centre, and the establishment of a lipid standardization programme in conjunction with that in Atlanta, Georgia. The mean interval between the myocardial infarct and the date when measurements were made was 13.9 weeks, and it is unlikely that the infarct will have much consistent influence at this stage.

Though we have always reported the results for the whole range of the population, we have, for practical reasons, introduced arbitrary cutting points and they were relatively high in this study.

The association between coronary heart disease and raised levels of plasma cholesterol and triglycerides is now firmly established (Carlson and Böttiger, 1972; Albrink, Meigs, and Man, 196r; Doyle and Kannel, 1970; Kannel et al., 1971; Epstein and Ostrander, 1971; Ostrander et al., 1967; Page et al., 1970; Goldstein et al., 1973). The results of the present study show that, using a cutting point of $7.25 \mathrm{mmol} / 1(280 \mathrm{mg} / \mathrm{dl})$ for cholesterol, 25 per cent of all patients studied were above this level, and for triglycerides 35 per cent of all patients were above a level of $2.26 \mathrm{mmol} / \mathrm{l}$ $(200 \mathrm{mg} / \mathrm{dl})$. There were interesting differences in the prevalence of hypercholesterolaemia and hypertriglyceridaemia: raised serum cholesterol and triglyceride levels were common in all seven highly developed countries but uncommon in Bombay and Singapore. The cause of these low lipid levels is not known but dietary habits probably play an important role (Keys, I970).

Cigarette smoking is now firmly established as a risk factor for coronary heart disease (Doll and Hill, 1956; Doyle et al., 1962, 1964; Kannel, 1966; Truett, Cornfield, and Kannel, 1967). Eighty per cent of all patients smoked, most of them more than 15 cigarettes per day. This high figure is in accordance with the findings of Blacket et al. (1973) who found a similar proportion among his patients with coronary heart disease.

Hypertension also is a well-documented risk factor for the development of coronary heart disease (Doyle and Kannel, 1970; Kannel, Castelli, and McNamara, 1967; Stamler, 1967; Primary Prevention of the Atherosclerotic Diseases, 1970), but is, as the Framingham analysis shows (Truett et al. 
1967), less important at this age than in higher agegroups. All the same, we found that 15 per cent of all patients had either known and treated hypertension before the myocardial infarct or raised blood pressure after the infarct. The prevalence of hypertension ranged from 23 to 7 per cent, with Melbourne and Auckland at the top of the scale and Edinburgh and Singapore at the bottom.

There were interesting differences in the prevalence of obesity. In Heidelberg, Cape Town, and Tel Aviv, obesity (relative body weight over 0.28) occurred in about one-third of the patients, while obesity was uncommon or absent in Edinburgh, Singapore, Melbourne, and Bombay. The relative body weight and lipid levels were both low in Bombay and Singapore, while the low relative body weight in Melbourne corresponded to the low serum cholesterol levels.

Regardless of varying diagnostic classification, carbohydrate intolerance is a well-documented risk factor (Epstein and Ostrander, 1971 ; Reaven et al., 1963; Ostrander et al., 1965; Keen et al., 1965). Our results show that 5 per cent of all patients were treated for diabetes before the myocardial infarct and 8 per cent of those in whom a glucose tolerance test was performed had an abnormal response one and a half to six months after infarction. This figure of 8 per cent is probably too low, as 29 per cent of all patients in Bombay had a fasting glucose over $6.66 \mathrm{mmol} / 1$ (120 mg/dl), yet no glucose tolerance test was carried out. Diabetes is known to be common in this part of India (Berry et al., 1966). Low fasting glucose levels in Edinburgh have been recorded before (Oliver et al., 1975).
The importance of high uric acid levels as a risk factor for coronary heart disease is still being debated, though there is no doubt that gout itself is important (Kannel et al., 1967; Hall, 1965). Our study revealed big differences between the different centres with an especially high prevalence of hyperuricaemia in Los Angeles/Atlanta and Cape Town.

The prevalence of a positive family history for coronary heart disease was high in some western centres; but it is difficult to compare the results between the different countries as the reliability of the history taken may vary greatly, especially in Bombay and Singapore.

A combined computer analysis for the three major risk factors, hyperlipidaemia (as defined), cigarette smoking, and hypertension is shown in Table 7. Eighty-nine per cent of all patients had one or more than one of these major risk factors. Forty-eight per cent had one, 34 per cent had two, and 7 per cent had three of these factors. This Table shows clearly that the two centres, Bombay and Singapore, have a much lower prevalence of these risk factors than the other seven centres $(P<0.01)$. In Bombay and Singapore, serum cholesterol, serum triglycerides, and serum uric acid levels were low and obesity was uncommon. Only the prevalence of cigarette smoking and diabetes was in the same range as in the western centres. In these other seven centres, there was in general a high prevalence of combined risk factors, as shown in the analysis of the three major risk factors (Table 7). Hypercholesterolaemia, hypertriglyceridaemia, and cigarette smoking were very common in all these seven centres. Influences such as excess relative body weight, hyperglycaemia,

TABLE 7 Major risk factors

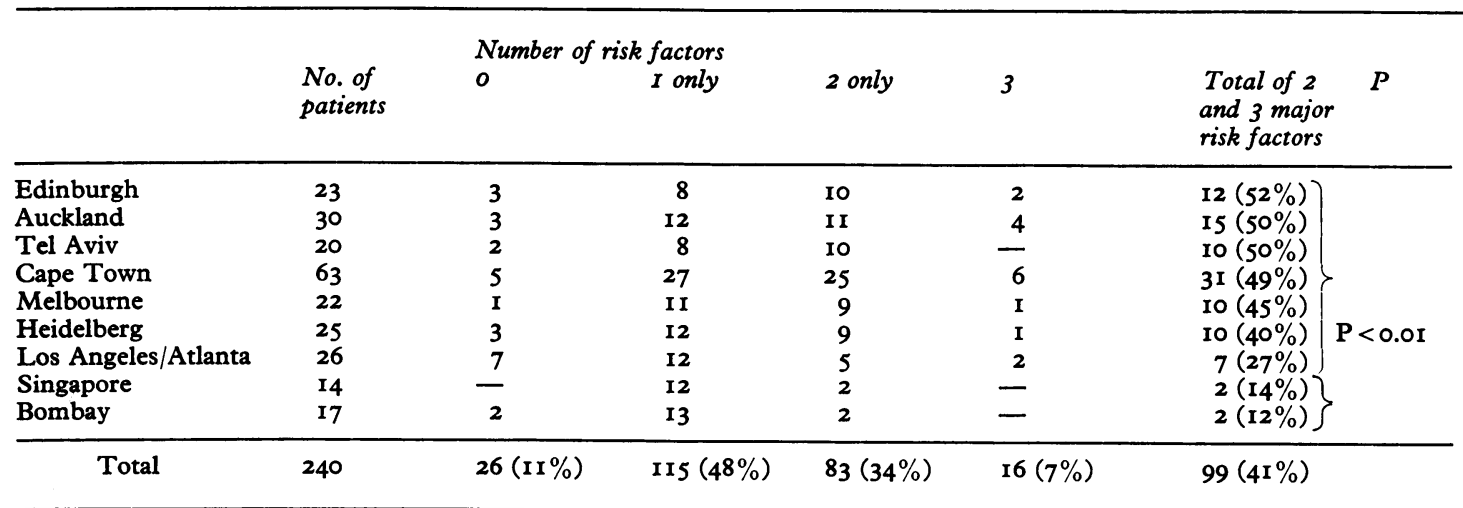

Major risk factors $=\mathrm{I}$. Cholesterol $\geqslant 7.25 \mathrm{mmol} / 1$ and/or triglycerides $\geqslant 2.26 \mathrm{mmol} / \mathrm{l}$.

2. Cigarette smoking (any number).

3. Hypertension (treated hypertension before MI, or systolic $\mathrm{BP} \geqslant 2 \mathrm{r} .3 \mathrm{kPa}$, or diastolic $\mathrm{BP} \geqslant 14.6$ $\mathrm{kPa}$ ).
Conversion factors from $S I$ units to traditional units: Cholesterol $\mathrm{r} \mathrm{mmol} / 1 \approx 38.6 \mathrm{mg} / \mathrm{dl}$.

Triglyceride I mmol/1 $\approx 88.5 \mathrm{mg} / \mathrm{dl}$.

Blood pressure I $\mathrm{kPa} \approx 7.5 \mathrm{mmHg}$. 
and hyperuricaemia varied in prevalence from centre to centre.

This study allows two main conclusions. First, there is a striking difference in the prevalence of risk factors in young men who have survived a myocardial infarct, between Bombay and Singapore on the one hand and the seven other countries on the other hand. Second, the study indicates the prevalence of the various risk factors in male survivors of myocardial infarcts aged 40 or less in each centre and emphasizes to each centre where further studies might profitably be directed.

We wish to thank Mrs. Serena Shankland for coding electrocardiograms; Mrs. Carol Bradley, Mrs. Lynn Chalmers, Mrs. Sandra Brown, and Mrs. Eva Riemersma, for their data processing with the computer.

\section{References}

Albrink, M. J., Meigs, J. W., and Man, E. B. (196I). Serum lipids, hypertension and coronary artery disease. American fournal of Medicine, 31, 4.

Berry, J. N., Chakravarty, R. N., Gupta, H. D., and Malik, K. (I966). Prevalence of diabetes mellitus in a north Indian town. Indian fournal of Medical Research, 54, 1025.

Blacket, R. B., Leelarthaepin, B., Palmer, A. J., and Woodmill, J. M. (1973). Coronary heart disease in young men: a study of seventy patients with a critical review of etiological factors. Australian and New Zealand fournal of Medicine, 3, 39.

Carlson, L. A., and Böttiger, L. E. (1972). Ischaemic heartdisease in relation to fasting value of plasma triglycerides and cholesterol. Lancet, $1,865$.

Doll, R., and Hill, A. B. (1956). Lung cancer and other causes of death in relation to smoking: second report on mortality of British doctors. British Medical fournal, 2, 107I.

Doyle, J. T., Dawber, T. R., Kannel, W. B., Heslin, A. S., and Khan, H. A. (1962). Cigarette smoking and coronary heart disease. Combined experience of the Albany and Framingham studies. New England fournal of Medicine, 266, 796.

Doyle, J. T., Dawber, T. R., Kannel, W. B., Kinch, S. H., and Kahn, H. A. (1964). The relationship of cigarette smoking to coronary heart disease. The second report of the combined experience of the Albany, N.Y. and Framingham, Mass. studies. Fournal of the American Medical Association, 190, 886.

Doyle, J. T., and Kannel, W. B. (1970). Coronary risk factors: 1o years findings in 7446 Americans. Pooling Project, Council on Epidemiology; American Heart Association. Presented at the VI World Congress of Cardiology, London, England, September 6-12.

Epstein, F. H. (1965). The epidemiology of coronary heart disease; a review. Fournal of Chronic Diseases, 18, 735.

Epstein, F. H. (1973). Coronary heart disease epidemiology revisited: clinical and community aspects. Circulation, 48, 185 .

Epstein, F. H., and Ostrander, L. D. (1971). Detection of individual susceptibility toward coronary disease. Progress in Cardiovascular Diseases, 13, 324.

Fitzgerald, M. G., and Keen, H. (I964). Diagnostic classification of diabetes. Lancet, $1,1325$.

Goldstein, J. L., Hazzard, W. R., Schrott, H. G., Bierman, E. L., and Motulsky, A. G. (1973). Hyperlipidemia in coronary heart disease. Lipid levels in 500 survivors of myocardial infarction. Fournal of Clinical Investigation, 52, 1533.

Hall, A. P. (1965). Correlations among hyperuricemia, hypercholesterolemia, coronary disease and hypertension. Arthritis and Rheumatism, 8, 846.

Kannel, W. B. (1966). Habits and coronary heart disease. The Framingham heart study. U.S. Government Printing Office, Washington, D.C.

Kannel, W. B., Castelli, W. P., Gordon, T., and McNamara, P. M. (1971). Serum cholesterol, lipoproteins, and the risk of coronary heart disease. The Framingham study. Annals of Internal Medicine, 74, I.

Kannel, W. B., Castelli, W. P., and McNamara, P. M. (I967). The coronary profile. 12-year follow-up in the Framingham study. Fournal of Occupational Medicine, 9, 611.

Keen, H., Rose, G., Pyke, D. A., Boyns, D., Chlouverakis, C., and Mistry, S. (1965). Blood-sugar and arterial disease. Lancet, 2, 505.

Keys, A. (1970). Coronary heart disease in seven countries. Circulation, 41, Suppl. I.

Khosla, T., and Lowe, C. R. (1967). Indices of obesity derived from body weight and height. British fournal of Preventive and Social Medicine, 21, 122.

Metropolitan Life Insurance Company (1959). Rise in mortality last year. Statistical Bulletin, Metropolitan Life Insurance Company, 40, 1.

Oliver, M. F., Nimmo, I. A., Cooke, M., Carlson, L. A., and Olson, A. G. (1975). Ischaemic heart disease and associated risk factors in 40 year old men in Edinburgh and Stockholm. European fournal of Clinical Investigation (in press).

Ostrander, L. D., Jr., Francis, T., Jr., Hayner, N. S., Kjelsberg, M. O., and Epstein, F. H. (1965). The relationship of cardiovascular disease to hyperglycemia. Annals of Internal Medicine, 62, I 188.

Ostrander, L. D., Neff, B. J., Block, W. D., Francis, T., and Epstein, F. H. (1967). Hyperglycemia and hypertriglyceridemia among persons with coronary heart disease. Annals of Internal Medicine, 67, 34.

Page, I. H., Berrettoni, J. N., Butkus, A., and Sones, F. M. (1970). Prediction of coronary heart disease based on clinical suspicion, age, total cholesterol, and triglyceride. Circulation, 42, 625.

Primary Prevention of the Atherosclerotic Diseases (1970). Position Paper for the Intersociety Commission for Heart Disease Resources Prepared by the Atherosclerosis Study Group (J. Stamler, Chairman) and the Epidemiology Study Group (A. M. Lilienfeld, Chairman). Circulation, 42, A55.

Reaven, G., Calciano, A., Cody, R., Lucas, C., and Miller, K. (1963). Carbohydrate intolerance and hyperlipemia in patients with myocardial infarction without known diabetes mellitus. Fournal of Clinical Endocrinology and Metabolism, 23, 1013.

Stamler, J. (1967). Lectures on Preventive Cardiology. Grune and Stratton, New York and London.

Truett, J., Cornfield, J., and Kannel, W. (1967). A multivariate analysis of the risk of coronary heart disease in Framingham. Fournal of Chronic Diseases, 20, $51 \mathrm{I}$.

World Health Organization (1959). Hypertension and coronary heart disease. Classification and Criteria for Epidemiological Studies. World Health Organization, Technical Report Series, No. 168.

Requests for reprints to Dr. Michael F. Oliver, Department of Cardiology, Royal Infirmary, Edinburgh $\mathrm{EH}_{3}$ 9YW. 